\title{
PENGARUH PRAKTIK AKUNTANSI DENGAN PRINSIP KEHATI-HATIAN (PRUDENTIAL PRINCIPLE) TERHADAP KUALITAS LABA DAN TINGKAT PENGEMBALIAN SAHAM (STUDI EMPIRIS PADA PERUSAHAAN MANUFAKTUR YANG TERDAFTAR DI BEI)
}

\author{
Ana Septiani \\ Universitas muhammadiyah metro \\ anaseptiani137@gmail.com
}

\begin{abstract}
Abstrak: The financial statements provide information that contains performance and financial position of a company. The financial statements conform to the principles of accounting in accordance with generally accepted standards to be useful to users in decision making of economic. The financial statements that are useful are the financial statements of good quality and can be an indicator for future earnings in order to maximize the stock return and optimize the benefits for all stakeholders. This research is quantitative. The purpose of this study was to obtain empirical evidence about the effect of accounting practices with the prudential principle on the quality of earnings and stock returns. Variable measurement using indicators that are adapted to journal the adoption of this research that Penman and Zhang (2002), among others subscore consisting of inventory reserve, research and development reserves and advertising reserves, used to measure the accounting practices with the prudential principle, Qscore used to measure quality earnings and returns are used to measure stock returns. The population in this study are all companies listed on the Indonesia Stock Exchange period 2012 to 2014. The sample period is a manufacturing company that has made the convergence of IFRS. Total sample was 84 manufacturing company's financial statements every period of observation so that the total samples analyzed were as 252 manufacturing company financial statements for three periods of observation. Data analysis was performed with the classical assumption and hypothesis testing with multiple linear regression analysis. Statistical program in this study using SPSS 22.The results showed that subscore is the inventory reserves, research and development reserves and advertising reserves on accounting practices with the prudential principle to produce earnings quality is good, besides the results also showed that the stock market can "adapt" to new information one of which is the change in the quality of corporate profits caused by the research and development reserves on the accounting practices with the prudential principle in manufacturing.
\end{abstract}

Keyword: Accounting Practices with the Prudential Principle, Quality of Earnings and Stock return

AKUISISI : Jurnal Akuntansi dan Keuangan

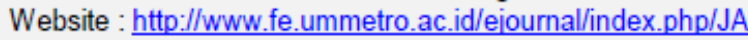

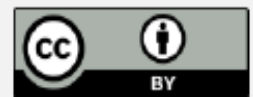

This is an open access article distributed under the terms of the Creative Commons Attribution 4.0 International License, which permits unrestricted use, distribution, and reproduction in any medium, provided the original work is properly cited.

\section{PENDAHULUAN}

International Accounting Standard (IAS) No.1 tentang penyajian laporan keuangan, di Indonesia diaplikasikan kedalam Pernyataan Standar Akuntansi Keuangan (PSAK) No. 1 tentang penyajian laporan keuangan mengatur dasar-dasar penyajianlaporan keuangan untuk tujuan umum dan komponen laporan keuangan agar dapatdibandingkandengan laporan keuangan perusahaan 
periode sebelumnya maupundengan laporan keuangan perusahaan lain.PSAK 1 tentang Penyajian Laporan Keuangan merupakan konvergensi dari IFRS secara penuh sejak tanggal 1 Januari 2012.International Financial Reporting Standard (IFRS) didasari oleh IAS 1. IFRS merupakan kumpulan dari standar akuntansi yang dikembangkan oleh International Accounting Standard Board (IASB) yang menjadi standar global untuk penyusunan laporan keuangan perusahaan publik.

IFRS mengatur bahwasetiap entitas harus menyusun laporan keuangan, kecuali untuk informasi arus kas, dengan menggunakan akrual sebagai dasar akuntansi.Pada saat akuntansi berbasis akrual digunakan, maka entitas mengakui item sebagai aset, kewajiban, ekuitas, pendapatandan biaya (elemen dari laporan keuangan) ketika telah memenuhi definisi dan kriteria pengakuan untuk elemen-elemen dalam kerangka konseptual.IFRS juga mengharuskan pengungkapan yang lebih banyak, baik kuantitaif maupun kualitatif.Dalam menyajikan informasi yang berkualitas, akuntansi dihadapkan pada keterbatasan yaitu, pertimbangan antara biaya dan manfaat, prinsip materialitas, praktik industri dan konservatisme.

Konservatisme merupakan salah satuketerbatasan dalam kerangka konseptual yang keberadaannya semakin diminimalisir pasca konvergensi IFRSsejak diberlakukannya praktik akuntansi dengan prinsip kehati-hatian. Hal tersebut sesuai dengan hasil penelitian yang dilakukan oleh Hellman (2007)yang menyatakan bahwa kebutuhan konservatisme sering dikaitkan dengan keandalan pelaporan dari peristiwa masa lalu, konservatisme akuntansi tidak lagi menjadi prinsip yang diatur dalam standar akuntansi internasional (IFRS) karenasaat ini IFRS memperkenalkan prinsip baru yang disebut dengan praktik akuntansi dengan prinsip kehati-hatian sebagai pengganti dari prinsip konservatisme.

Hal tersebut berbanding terbalik dengan pendapat Penman dan Zhang (2002) yang menemukan bahwa perusahaan yang menerapkan akuntansi konservatif dan pertumbuhan investasi sementaraakan menghasilkan tingkat pengembalian yang sementara atau laba yang berfluktuasi. Hasil penelitian menemukan bahwa, ketika sebuah perusahaan mempraktekkan akuntansi konservatif, maka perubahan dalam jumlah investasi dapat mempengaruhi kualitas laba.

Penman dan Zhang (2002) melakukan penelitian tentang pengaruh dari konservatisme akuntansi terhadap kualitas laba dan tingkat pengembalian saham di Amerika.Hal tersebut dikarenakan Amerika menerapkan akuntansi konservatisme mengikuti pedoman dari SFAC 8 atau tidak menerapkan IFRS.Penelitian yang akan dilakukanadalah pengadopsian dari penelitian yang dilakukan oleh Penman dan Zhang (2002) denganmenguji pengaruh prinsip kehati-hatian akuntansi terhadap kualitas laba dan tingkat pengembalian saham. Hal tersebut disebabkan karena pasca konvergensi IFRS, Indonesia menerapkanakuntansi dengan prinsip kehati-hatian menggantikan konservatisme. 
Pengukuran akan dilakukan berdasarkan pendekatan tingkat pengembalian bersih pada aset operasional, Qscore dan Subscoredari akuntansi dengan prinsip kehati-hatian yaitu cadangan persediaan, cadangan penelitian dan pengembangan serta cadangan iklan menggunakan sampel dengan periode penelitian setelah konvergensi IFRS.

\section{KAJIAN PUSTAKA}

\section{Praktik Akuntansi dengan Prinsip Kehati-hatian}

Praktik akuntansi dengan prinsip kehati-hatian mengacu pada PSAK 1 tentang Penyajian Laporan Keuangan yang mengikuti Standar Akuntansi Internasional (IAS 1) yang menjadi dasar konvergensi IFRS mulai tahun 2008-2011, dan wajib diimplementasikan secara penuh sejak 1 Januari 2012. IFRS menggunakan basis akrual sebagai dasar akuntansi yaitu pendapatan boleh diakui meskipun masih berupa potensi.Praktik akuntansi dengan prinsip kehati-hatian menggantikan praktik akuntansi konservatisme yang menjadi kendala dalam kerangka konseptual laporan keuangan.

\section{Kualitas Laba}

Kualitas laba merupakan suatu penyajian informasi tentang laba suatu instansi yang sesuai dengan laba sebenarnnya sehingga informasi yang di dapat dari laporan laba tidak menyesatkan kreditor dan investor dalam pengambilan keputusan.Kerangka konseptual dapat membantu dalam menyediakan pedoman struktur dan arah untuk akuntansi dan pelaporan keuangan serta memfasilitasi penyediaan kualitas informasi keuangan yang baik dan tidak mengandung bias.

PSAK 1 tentang Penyajian Laporan Keuangan merupakan adopsi dari IAS 1 menjadi dasar konvergensi IFRS.Kerangka konseptual perlaporan keuangan berdasarkan IAS 1 adalah sebagai berikut: 
KERANGKA KONSEPTUAL BERDASARKAN IAS 1

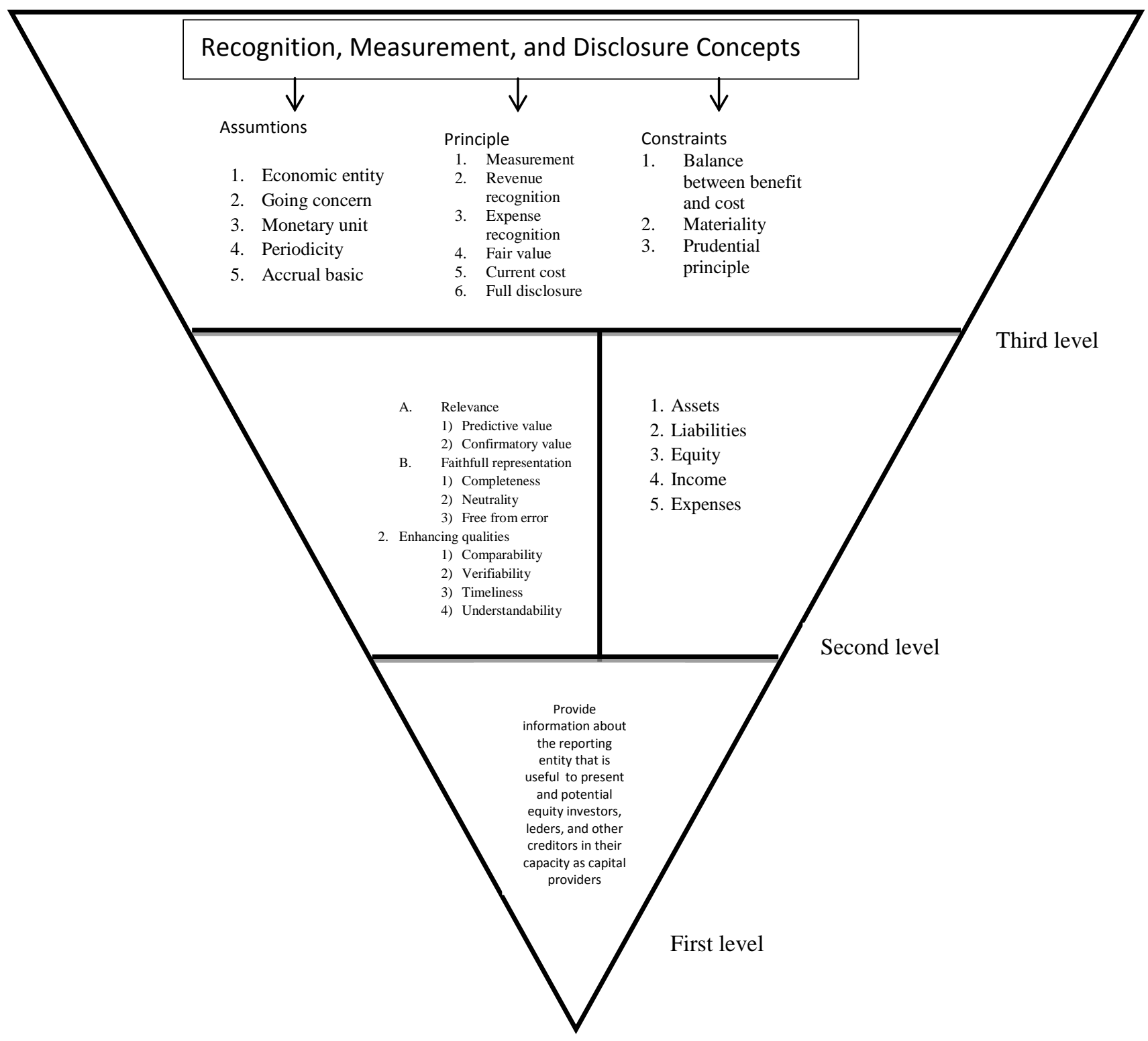

Gambar 1. Kerangka Konseptual Berdasarkam IAS 1

Sumber : Kieso et al (2011) 


\section{Tingkat Pengembalian Saham}

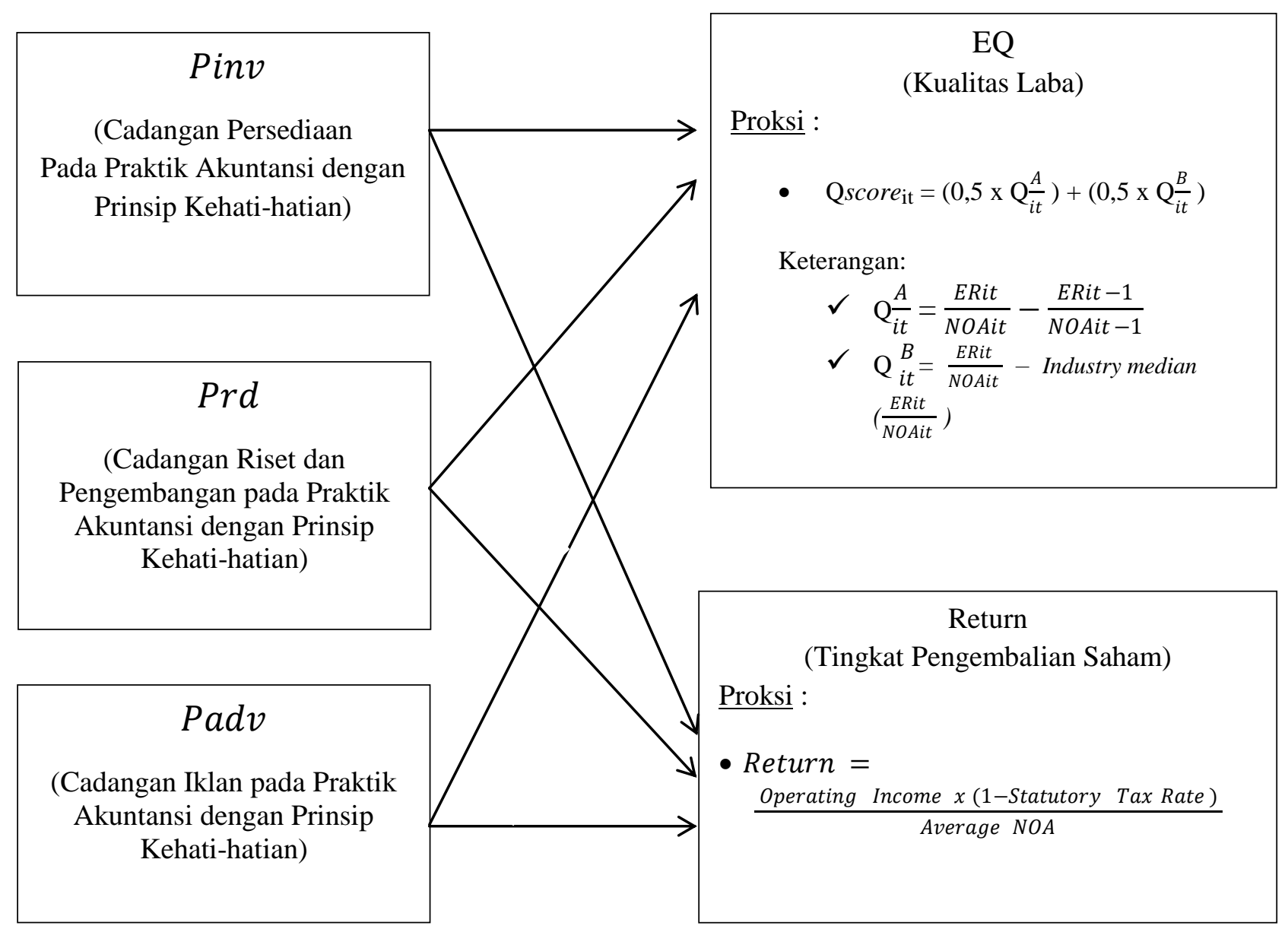

Gambar 2. Tingkat Pembelian Saham

\section{Pengembangan Hipotesis}

1. Pengaruh antara Cadangan Persediaan pada Praktik Akuntansi dengan Prinsip Kehatihatian terhadap Kualitas Laba dan Tingkat Pengembalian Saham

Apabila pencatatan dan pengakuan persediaan dengan jumlah yang lebih rendah, maka hal tersebut dapat meningkatkan cadangan.Perusahaan yang menerapkan praktik akuntansi dengan prinsip kehati-hatian akan meminimalisir adanya cadangan melalui pencatatan dan pengakuan yang sebenarnya. Oleh karena itu diharapkan laba yang dihasilkan dapat menjadi indikator yang baik sehingga tingkat pengembalian saham saat ini dapat menjadi prediksi yang tepat bagi pengharapan tingkat pengembalian saham masa depan.

H1: Cadangan Persediaan pada Praktik akuntansi dengan prinsip kehati-hatian berpengaruh positif terhadap kualitas laba.

H2: Cadangan Persediaan pada Praktik akuntansi dengan prinsip kehati-hatian berpengaruh positif terhadap Tingkat Pengembalian saham. 
2. Pengaruh antara Cadangan Riset dan Pengembangan pada Praktik Akuntansi dengan Prinsip Kehati-hatian terhadap Kualitas Laba dan Tingkat Pengembalian Saham

Pembebanan pada riset dan pengembangan yang lebih cepat menyebabkan laba periode saat ini menjadi rendah.Praktik akuntansi dengan prinsip kehati-hatian mengakui adanya penurunan kewajiban dan beban dengan suatu kondisi memenuhi kriteria pengakuan elemen laporan keuangan, sehingga diharapkan laba yang dihasilkan dapat menjadi indikator yang baiksehingga tingkat pengembalian saham saat ini dapat menjadi prediksi yang tepat bagi pengharapan tingkat pengembalian saham masa depan.

H3: Cadangan Riset dan Pengembangan pada Praktik akuntansi dengan prinsip kehati-hatian berpengaruh positif terhadap kualitas laba.

H4: Cadangan Riset dan Pengembangan pada Praktik akuntansi dengan prinsip kehati-hatian berpengaruh positif terhadap Tingkat Pengembalian saham.

\section{Pengaruh antara Cadangan Iklan pada Praktik Akuntansi dengan Prinsip Kehati-hatian} terhadap Kualitas Laba dan Tingkat Pengembalian Saham

Pembebanan segera pengeluaran periklanan adalah konservatif akan menekan pendapatan saat ini dan menyebabkan peningkatan pada cadangan iklan. Apabila perusahaan menerapkan praktik akuntansi dengan prinsip kehati-hatianakanmengakui adanya kenaikan aset atau penurunan kewajiban dan beban dengan suatu kondisi telah memenuhi kriteria pengakuan laporan keuangan, sehingga diharapkan laba yang dihasilkan dapat menjadi indikator yang baik dari pendapatan masa depan.

H5: Cadangan Iklan pada Praktik akuntansi dengan prinsip kehati-hatian berpengaruh positif terhadap kualitas laba.

H6: Cadangan Iklan pada Praktik akuntansi dengan prinsip kehati-hatian berpengaruh positif terhadap Tingkat Pengembalian saham.

\section{METODOLOGI PENELITIAN}

\section{Populasi dan Sampel}

Penelitian ini merupakan penelitian kuantitatif, dengan menggunakan analisis regresi linier berganda untuk menguji pengaruh praktik akuntansi dengan prinsip kehati-hatian yang ditinjau dari subscore nya yaitu cadangan persediaan, cadangan riset dan pengembangan serta cadangan iklan terhadap kualitas laba dan tingkat pengembalian saham. Data dalam penelitian ini menggunakan data sekunder.Jenis data yang digunakan bersifat runtut waktu dari tahun 2012-2014.Data sekunder dalam penelitian ini adalah laporan keuangan auditan dan laporan keuangan tahunan perusahaan manufaktur yang terdaftar di Bursa Efek Indonesia (BEI).Data yang digunakan diperoleh dari 
Pengaruh Praktik Akuntansi

website Bloomberg dan website IDX. Pengambilan sampel dilakukan dengan menggunakan metode random sampling

\section{Variabel Penelitian dan Definisi Operasional}

\section{Variabel Independen}

Variabel independendalam penelitian ini adalah praktik akuntansi dengan prinsip kehatihatian yang terdiri dari subscore cadangan persediaan, cadangan riset dan pengembangan serta cadangan iklan.

\section{a. Cadangan Persediaan}

Cadangan persediaan merupakan cadangan yang diciptakan dari perubahan estimasi pengakuan kerugian persediaan.Cadangan persediaan dinilai dengan membagi cadangan persediaan yang diperoleh dari website Bloomberg dengannet operating assets pada laporan posisi keuangan melalui persamaan sebagai berikut:

$$
\text { Pinv }_{i t}==\frac{I N V_{i t}^{\text {res }}}{\text { NOA }_{i t}}
$$

Keterangan :

Pinv = Cadangan persediaan sebagai subscore pertama dari praktik akuntansi dengan prinsip kehati-hatian.

$i \quad=$ Perusahaan.

Inv $v_{\text {res }}=$ Cadangan Persediaan perusahaan yang dilaporkan dalam website

Bloomberg.

$t \quad=$ Tahun penelitian.

NOA = Net operating assets (Aset operasional dikurangi dengan kewajiban operasional.

\section{b. Cadangan Riset dan Pengembangan}

Cadangan riset dan pengembangan merupakan cadangan yang diciptakan melalui percepatan pengakuan beban riset dan pengembangan.Cadangan riset dan pengembangan dinilai dengan membagi cadangan riset dan pengembangan yang diperoleh dari website Bloomberg dengan net operating assets pada laporan posisi keuangan melalui persamaan sebagai berikut:

$$
\begin{aligned}
& P r d_{i t}=R D_{i t}^{\begin{array}{c}
r e s \\
i t
\end{array}} \\
& N O A_{i t}
\end{aligned}
$$

Keterangan :

$$
\begin{array}{ll}
\text { Prd } & \text { = Cadangan riset dan pengembangan sebagai subscore kedua dari } \\
& \text { praktik akuntansi dengan prinsip kehati-hatian. } \\
i & =\text { Perusahaan. } \\
R D_{\text {res }} & =\text { Cadangan riset dan pengembangan perusahaan yang dilaporkan } \\
& \begin{array}{l}
\text { dalam website Bloomberg. } \\
\text { = Tahun penelitian. }
\end{array} \\
N O A \quad \text { Net operating assets (Aset operasional dikurangi dengan } \\
\text { kewajiban operasional. }
\end{array}
$$




\section{c. Cadangan Iklan}

Cadangan iklan adalah cadangan yang diciptakan dari percepatan pengakuan beban iklan.Cadangan iklan dinilai dengan membagi cadangan iklan yang diperoleh dari website

Bloomberg dengan net operating assets pada laporan posisi keuangan melalui persamaan sebagai berikut:

$$
\operatorname{Prd}_{i t}==\frac{A D V_{i t}^{r e s}}{N O A_{i t}}
$$

Keterangan :

Padv = Cadangan iklan sebagai subscore kedua dari praktik akuntansi dengan prinsip kehati-hatian.

$i \quad=$ Perusahaan.

$A D V_{\text {res }}=$ Cadangan iklan perusahaan yang dilaporkan dalam website

Bloomberg.

$t \quad=$ Tahun penelitian.

NOA = Net operating assets (Aset operasional dikurangi dengan kewajiban operasional.

\section{Variabel Dependen}

Variabel dependen dalam penelitian ini terdiri dari kualitas laba dan tingkat pengembalian saham

\section{a. Kualitas laba}

Kualitas laba merupakan suatu penyajian informasi tentang laba suatu perusahaan yang sesuai dengan laba wajar sesuai dengan prinsip yang berlaku umum dan terbebas dari salah saji material. Indikator kualitas laba yang digunakan dalam penelitian ini adalah Qscore yang digunakan untuk mengukur pengaruh dari praktik akuntansi dengan prinsip kehatihatian pada pendapatan dalam laporan laba rugi.

Kualitas laba diproksikan dengan Qscorediperoleh melalui menjumlahkan antara QA dengan QB yaitu:

$$
\mathrm{Q}_{\text {score }} \mathrm{it}=\left(0,5 \times \mathrm{Q} \frac{A}{i t}\right)+\left(0,5 \times \mathrm{Q}_{i t}^{B}\right)
$$

Keterangan :

Qscore = Kualitas laba suatu perusahaan .

$i \quad=$ Perusahaan.

$t \quad=$ Tahun penelitian.

$Q A \quad=$ Perubahan scoredari praktik akuntansi dengan prinsip kehati-hatiansuatu Perusahaan.

$Q B \quad=$ Perbandingan Pscore perusahaan pada nilai tengah industri. 
Berikut penjelasan dari masing-masing komponen Qscore:

a) QA dihitung dengan rumus:

$$
Q \frac{A}{i t}=\frac{E R i t}{\text { NOAit }}-\frac{\text { ERit }-1}{\text { NOAit }-1}
$$

Keterangan :

$Q A \quad=$ Perubahan scoredari praktik akuntansi dengan prinsip kehatihatiansuatu perusahaan.

$i \quad=$ Perusahaan.

$t=$ Tahun penelitian.

ER = Estimasi cadangan dihitung melalui penjumlahan dari masing masingsubscore dari akuntansi dengan prinsip kehati-hatian yaitu cadanganpersediaan, cadangan riset dan pengembangan serta cadangan iklan.

NOA = Net operating assets (Aset operasional dikurangidengan kewajibanoperasional.

\section{b) QB dihitung dengan rumus}

$$
Q_{i t}^{B}=\frac{\text { ERit }}{\text { NOAit }}-\text { Industry median }\left(\frac{\text { ERit }}{\text { NOAit }}\right)
$$

Keterangan :

$Q B \quad=$ Perbandingan Pscore perusahaanpada nilai tengah industri.

$i \quad=$ Perusahaan.

$t \quad=$ Tahun penelitian.

ER = Estimasi cadangan dihitung melalui penjumlahan dari masing-masingsubscore dari akuntansi dengan prinsip kehati-hatian yaitu cadanganpersediaan, cadangan riset dan pengembangan serta cadangan iklan.

NOA = Net operating assets (Aset operasional dikurangi dengan kewajiban operasional.

Industry median=Nilai tengah estimasi cadangan rata-rata industri selama periodepengamatan.

\section{b. Variabel Tingkat PengembalianSaham}

Tingkat pengembalian saham merupakan suatu komponen yang diterima investor yang terdiri dari yield (aliran kas atau pendapatan yang diperoleh secara periodik dari suatu investasi) dan capital gain (kenaikan harga suatu surat berharga yang terdiri dari saham atau surat utang jangka panjang) yang diperoleh akibat dari perubahan harga saham sebagai dampak dari reaksi pasar karena adanya penyampaian informasi keuangan suatu perusahaan dalam pasar modal.

Pengujian tingkat pengembalian saham suatu perusahaan digunakan untuk menilai bagaimana kualitas laba dapat memprediksi perubahan dalam tingkat pengembalian saham perusahaan.Tingkat pengembalian dihitung melalui rumus: 
Return $_{i t}=\left[\right.$ Operating income $_{i t} x\left(1-\right.$ Statutory tax rate $\left.\left._{i t}\right)\right] /$ Average $N O A_{i t}$

Keterangan :

Return $\quad=$ Tingkat pengembalian saham .

$i \quad=$ Perusahaan.

$t \quad=$ Tahun penelitian.

Operating Income = Pendapatan operasional sebelum bunga, pos luar biasa, dan

operasional yang tak dilanjutkan.

Statutory tax rate = Pajak antara aktivitas operasi dan pendanaan.

Average $N O A=$ Net operating assets rata-rata industri.

\section{Metode Analisis Data}

Penelitian ini menggunakan teknik analisis regresi linier berganda.Model regresi linier bergandadigunakan dalam penelitian ini untuk menguji pengaruh antara satu variabel terikat (dependen) dengan dua atau lebih variabel bebas (independen).(Latan, 2001). Secara sistematis, persamaan model dalam penelitian ini adalah sebagai berikut :

1) Model pertama (pengujian praktik akuntansi dengan prinsip kehati-hatian terhadap kualitas laba)

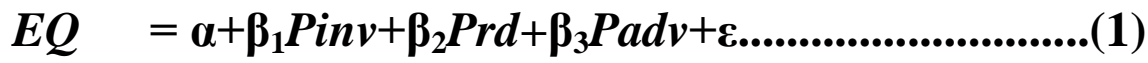

Keterangan :

Pinv =Cadangan persediaan pada praktik akuntansi dengan prinsip kehati-hatian.

Prd = Cadangan riset dan pengembangan pada praktik akuntansi dengan prinsip

kehati-hatian

$P a d v=$ Cadangan iklan pada praktik akuntansi dengan prinsip kehati-hatian .

$E Q \quad=$ Kualitas laba.

$\alpha=$ konstanta (titik potong antara garis regresi dengan sumbu Y).

$\beta=$ Koefisien regresi.

$\varepsilon \quad=$ Tingkat kesalahan penduga dalam penelitian.

2) Model kedua (pengujian praktik akuntansi dengan prinsip kehati-hatian terhadap tingkat pengembalian saham)

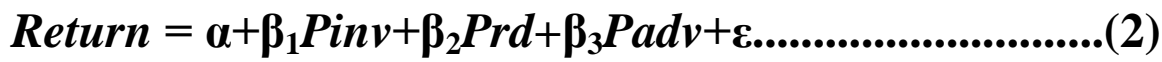

Keterangan :

Pinv = Cadangan persediaan pada praktik akuntansi dengan prinsip kehati-hatian .

Prd = Cadangan riset dan pengembangan pada praktik akuntansi dengan prinsip

kehati-hatian

Padv = Cadangan iklan pada praktik akuntansi dengan prinsip kehati-hatian.

Return $=$ Tingkat pengembalian saham.

$\alpha \quad=$ konstanta (titik potong antara garis regresi dengan sumbu Y).

$\beta=$ Koefisien regresi.

$\varepsilon \quad=$ Tingkat kesalahan penduga dalam penelitian. 
Pengaruh Praktik Akuntansi

\section{HASIL DAN PEMBAHASAN}

\section{Uji Asumsi Klasik}

Pengujian asumsi klasik dilakukan masing-masing sebanyak dua kali antara lain pada model pertama yaitu antara subscore cadangan persediaan, cadangan riset dan pengembangan serta cadangan iklan sebagai proksi dari praktik akuntansi dengan prinsip kehati-hatian dan Qscore sebagai proksi dari kualitas laba dan pada model kedua yaitu antara subscore cadangan persediaan, cadangan riset dan pengembangan serta cadangan iklan sebagai proksi dari praktik akuntansi denganprinsip kehati-hatian dan return sebagai proksi dari tingkat pengembalian saham.

\section{Uji Normalitas}

Hasil pengujian model menunjukkan hasil bahwa besarnya nilai Kolmogrov-Smirnov adalah 1.025 dan Asymp.sig. (2-tailed) pada 0.244 untuk model pertama dan nilai Kolmogrov-Smirnov adalah 1.273 dan Asymp.sig. (2-tailed) pada 0.078 untuk model kedua yaitu diatas $\alpha=0.05$ sehingga dapat disimpulkan bahwa data terdistribusi normal.

\section{Uji Multikolonieritas}

Pengujian pada model pertamadan kedua menunjukkan hasil bahwa tidak ada variabel independen yang memiliki nilai tolerance kurang dari 0.10 yang berarti bahwa tidak ada korelasi antar variabel independen yang nilainya lebih dari 95\%. Selain itu, nilai Variance Inflation Factor (VIF) juga menunjukkan bahwa tidak ada variabel independen yang memiliki nilai VIF lebih dari 10, maka dapat disimpulkan bahwa pada model tidak terdapat multikolonieritas antar variabel independen.

\section{Uji Autokorelasi}

Pengujian autokorelasi pada model pertama menunjukkan hasil bahwa nilai $D W$ adalah sebesar 1.806, dan pengujian pada model kedua menunjukkan hasil bahwa nilai $D W$ adalah sebesar 1.846.Nilai $D W$ kedua model lebih besar jika dibandingkan dengan batas atas (du) yaitu sebesar 1.799, maka dapat disimpulkan bahwa tidak terdapat autokorelasi pada kedua model.

\section{Uji Heteroskedastisitas}

Hasil pengujian menunjukkan hasil bahwa berdasarkan grafik scatterplots kedua model terlihat bahwa titik-titik menyebar secara acak serta tersebar baik di atas maupun di bawah angka 0 pada sumbu Y. Hal tersebut dapat disimpulkan bahwa tidak terjadi heteroskedastisitas pada kedua model model regresi. 


\section{Uji Hipotesis}

\section{a. Koefisien Determinasi}

Tabel 4.1 menunjukkan hasil nilai adjusted R2 adalah 0.965 , hal tersebut menunjukkan bahwa 96.5\% variasi Subscore dapat dijelaskan oleh variasi dari Qscore, sedangkan sisanya sebanyak $3.5 \%$ dijelaskan oleh sebab-sebab yang lain diluar model.

Tabel 4.1 Koefisien Determinasi Proksi Subscore Dengan Proksi Qscore

Model Summary

\begin{tabular}{|c|c|c|c|c|}
\hline Model & $\mathrm{R}$ & R Square & Adjusted R Square & $\begin{array}{l}\text { Std. Error of the } \\
\text { Estimate }\end{array}$ \\
\hline 1 & $.982^{\mathrm{a}}$ & .965 & .965 & .13398 \\
\hline
\end{tabular}

a. Predictors: (Constant), CadanganRisetdanPengembangan, CadanganIklan, CadanganPersediaan

b. Dependent Variable: Qscore

Tabel 4.2 menunjukkan hasil nilai adjusted $\mathrm{R}^{2}$ adalah 0.313 , hal tersebut menunjukkan bahwa $31.3 \%$ variasi Subscore dapat dijelaskan oleh variasi dari return, sedangkan sisanya sebanyak $68.7 \%$ dijelaskan oleh sebab-sebab yang lain diluar model

Tabel 4.2 Koefisien Determinasi Proksi Cscore Dengan Proksi Return

Model Summary

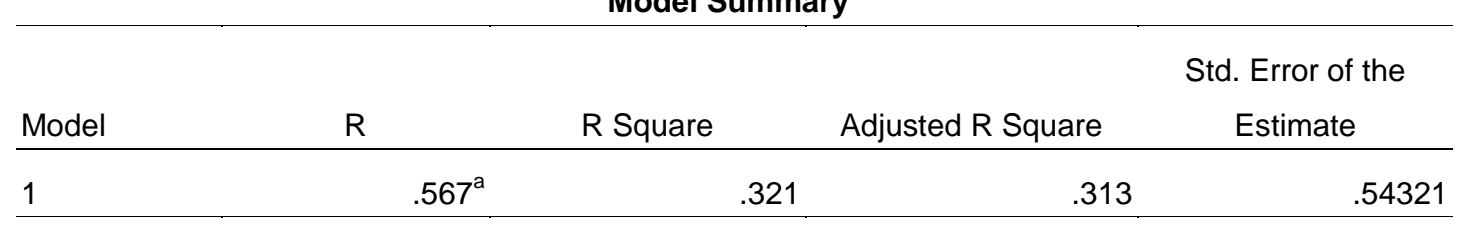

a. Predictors: (Constant), CadanganRisetdanPengembangan, Cadanganlklan, CadanganPersediaan

b. Dependent Variable: Return

b. Pengujian Pengaruh antara Praktik Akuntansi dengan Prinsip Kehati-hatian terhadap Kualitas Laba

Pengujian pengaruh antara praktik akuntansi dengan prinsip kehati-hatian terhadap kualitas laba digunakan untuk menguji tiga hipotesis yaitu hipotesis pertama, hipotesis ketiga dan hipotesis kelima. 
Pengaruh Praktik Akuntansi

\section{Uji Signifikansi Simultan (Uji Statistik F)}

Tabel 4.3 menunjukkan hasil bahwa besarnya nilai Fhitung adalah 2289.943 dengan probabilitas 0.000 . Nilai tersebut lebih kecil dari taraf signifikansi 0,05 yang artinya bahwa model regresi pertama dapat digunakan untuk memprediksi kualitas laba atau dapat disimpulkan bahwa subscore secara bersama-sama berpengaruh terhadap kualitas laba.

Tabel 4.3 Uji Signifikansi Simultan Proksi Subscore Dengan Proksi Qscore

\begin{tabular}{|c|c|c|c|c|c|}
\hline \multicolumn{6}{|c|}{ ANOVA $^{b}$} \\
\hline Model & Sum of Squares & Df & Mean Square & $\mathrm{F}$ & Sig. \\
\hline Regression & 123.313 & 3 & 41.104 & 2289.943 & $.000^{\mathrm{a}}$ \\
\hline Residual & 4.452 & 248 & .018 & & \\
\hline Total & 127.765 & 251 & & & \\
\hline
\end{tabular}

a. Predictors: (Constant), CadanganRisetdanPengembangan, CadanganIklan, CadanganPersediaan

b. Dependent Variable: Qscore

\section{Uji Parsial (Uji Statistik t)}

Hasil uji parsial antara Subscore dengan Qscore sebagai proksi dari kualitas laba dapat dilihat pada Tabel 4.4

Tabel 4.4 Uji Parsial Proksi Subscore Dengan Proksi Qscore

\section{Coefficients $^{\mathrm{a}}$}

\begin{tabular}{|c|c|c|c|c|c|c|}
\hline \multirow{2}{*}{\multicolumn{2}{|c|}{ Model }} & \multicolumn{2}{|c|}{$\begin{array}{c}\text { Unstandardized } \\
\text { Coefficients }\end{array}$} & \multirow{2}{*}{$\begin{array}{l}\text { Standardized } \\
\text { Coefficients } \\
\text { Beta }\end{array}$} & \multirow[b]{2}{*}{$\mathrm{T}$} & \multirow[b]{2}{*}{ Sig. } \\
\hline & & $\mathrm{B}$ & Std. Error & & & \\
\hline \multirow[t]{5}{*}{1} & (Constant) & 1.451 & .021 & & 68.282 & .000 \\
\hline & Cadangan Iklan & .023 & .003 & .101 & 7.307 & .000 \\
\hline & Cadangan Persediaan & .903 & .016 & .883 & 57.463 & .000 \\
\hline & Cadangan Riset dan & .077 & .015 & .076 & 5.146 & .000 \\
\hline & Pengembangan & & & & & \\
\hline
\end{tabular}

a. Dependent Variable: Qscore 
Berdasarkan hasil regresi uji parsial model pertama, maka dapat disusun persamaan matematika dari studi ini sebagai berikut:

$$
\text { Quality }=1.451+0.903 \text { INVres }+0.077 \text { RDres }+0.023 \text { ADVres }
$$

Pada tabel 4.4 yang menunjukkan hasil bahwa probabilitas signifikansi variabel Subscore sebesar 0.000. Nilai tersebut lebih kecil dari taraf signifikansi 0,05 yang artinya bahwa Ho berhasil ditolak sehingga masing-masing variabel independen (praktik akuntansi dengan prinsip kehatihatian) secara individual mempengaruhi variabel dependen (kualitas laba) dapat diterima.

\section{c. Pengujian Pengaruh antara Praktik Akuntansi dengan Prinsip Kehati-hatian terhadap Tingkat Pengembalian saham}

Pengujian pengaruh antara praktik akuntansi dengan prinsip kehati-hatian terhadap tingkat pengembalian saham digunakan untuk menguji tiga hipotesis yaitu hipotesis kedua, hipotesis keempat dan hipotesis keenam.

\section{Uji Signifikansi Simultan (Uji Statistik F)}

Tabel 4.5 menunjukkan hasil bahwa nilai Fhitung adalah 39.124 dengan probabilitas 0.000 . lebih kecil dari taraf signifikansi 0,05 sehingga dapat disimpulkan bahwa subscore dari praktik akuntansi dengan prinsip kehati-hatian yaitu cadangan persediaan, cadangan riset dan pengembangan serta cadangan iklan secara bersama-sama berpengaruh terhadap tingkat pengembalian saham.

Tabel 4.5 Uji Signifikansi Simultan Proksi Subscore Dengan Proksi Return

\begin{tabular}{|c|c|c|c|c|c|c|}
\hline \multicolumn{7}{|c|}{ ANOVA $^{b}$} \\
\hline Model & & Sum of Squares & Df & Mean Square & $\mathrm{F}$ & Sig. \\
\hline \multirow[t]{3}{*}{1} & Regression & 34.634 & 3 & 11.545 & 39.124 & $.000^{\mathrm{a}}$ \\
\hline & Residual & 73.179 & 248 & .295 & & \\
\hline & Total & 107.813 & 251 & & & \\
\hline
\end{tabular}

a. Predictors: (Constant), CadanganRisetdanPengembangan, CadanganIklan, CadanganPersediaan

b. Dependent Variable: Return

\section{Uji Parsial (Uji Statistik t)}

Hasil uji parsial antara Subscore dengan return sebagai proksi dari tingkat pengembalian saham dapat dilihat pada Tabel 4.6 
Tabel 4.6. Uji parsial proksi subscore dengan proksi return

\begin{tabular}{|c|c|c|c|c|c|c|}
\hline \multicolumn{7}{|c|}{ Coefficients $^{\mathrm{a}}$} \\
\hline & & \multirow{2}{*}{\multicolumn{2}{|c|}{$\begin{array}{c}\text { Unstandardized } \\
\text { Coefficients }\end{array}$}} & \multirow{3}{*}{$\begin{array}{c}\text { Standardized } \\
\text { Coefficients } \\
\text { Beta }\end{array}$} & \multirow[b]{3}{*}{$\mathrm{T}$} & \multirow[b]{3}{*}{ Sig. } \\
\hline & & & & & & \\
\hline \multicolumn{2}{|c|}{ Model } & $\mathrm{B}$ & Std. Error & & & \\
\hline \multirow[t]{5}{*}{1} & (Constant) & .560 & .086 & & 6.502 & .000 \\
\hline & Cadangan Iklan & .020 & .013 & .099 & 1.621 & .106 \\
\hline & Cadangan Persediaan & .067 & .064 & .071 & 1.046 & .297 \\
\hline & Cadangan Riset dan & .442 & .061 & .472 & 7.280 & .000 \\
\hline & Pengembangan & & & & & \\
\hline
\end{tabular}

a. Dependent Variable: Return

Berdasarkan hasil regresi uji parsial model pertama, maka dapat disusun persamaan matematika dari studi ini sebagai berikut:

$$
\text { Return }=0.560+0.067 \text { INVres }+0.422 \text { RDres }+0.020 \text { ADVres }
$$

Tabel 4.14 yang menunjukkan hasil bahwa probabilitas signifikansi variabel Subscore yaituadalah cadangan persediaan mempunyai probabilitas signifikansi sebesar 0.297 , cadangan iklan mempunyai probabilitas signifikansi sebesar 0.106 dan cadangan riset dan pengembangan mempunyai probabilitas signifikansi sebesar 0.000. Nilai tersebut hanya subscore cadangan riset dan pengembangan yang memiliki probabilitas yang lebih kecil dari taraf signifikansi 0,05 yang artinya bahwa Ho berhasil ditolak untuk hipotesis keempat dan Ho tidak berhasil ditolak untuk hipotesis kedua dan hipotesis keenam, sehingga hanya variabel independen cadangan riset dan pengembangan sebagai subscore secara individual mempengaruhi variabel dependen (kualitas laba) dapat diterima

\section{Pembahasan}

\section{Pengaruh antara Cadangan Persediaan pada Praktik Akuntansi dengan Prinsip Kehati- Hatian terhadap Kualitas Laba}

Penelitian ini menerima hipotesis satu karena secara statistik cadangan persediaan yang diperoleh dari praktik akuntansi dengan prinsip kehati-hatian menghasilkan laba yang berkualitas baik (tidak sejalan dengan penelitian Penman dan Zhang (2002).

\section{Pengaruh antara Cadangan Persediaan pada Praktik Akuntansi dengan Prinsip Kehati- Hatian terhadap Tingkat Pengembalian Saham}

Penelitian ini menolak hipotesis kedua karena secara statistik pasar saham tidak mengikuti perubahan kualitas laba perusahaan yang disebabkan karena penurunan dari cadangan persediaan 
melalui praktik akuntansi dengan prinsip kehati-hatian (sejalan dengan penelitian Penman dan Zhang (2002).

Pengaruh antara Cadangan Riset dan Pengembangan pada Praktik Akuntansi dengan Prinsip Kehati-Hatian terhadap Kualitas Laba

Penelitian ini menerima hipotesis ketiga karena secara statistik cadangan riset dan pengembangan yang diperoleh dari praktik akuntansi dengan prinsip kehati-hatian menghasilkan laba yang berkualitas baik (tidak sejalan dengan penelitian sebelumnya yang dilakukan oleh Penman dan Zhang (2002).

Pengaruh antara Cadangan Riset dan Pengembangan pada Praktik Akuntansi dengan Prinsip Kehati-hatian terhadap Tingkat Pengembalian Saham

Penelitian ini menerima hipotesis keempat karena secara statistik pasar saham dapat menyesuaikan diri terhadap informasi baru dariperubahan kualitas laba perusahaan yang disebabkan karena penurunan dari cadangan riset dan pengembangan melalui praktik akuntansi dengan prinsip kehati-hatian (tidak sejalan dengan penelitian Penman dan Zhang (2002).

Pengaruh antara Cadangan Iklan pada Praktik Akuntansi dengan Prinsip Kehati-Hatian terhadap Kualitas Laba

Penelitian ini menerima hipotesis kelima karena secara statistik cadangan iklan yang diperoleh dari praktik akuntansi dengan prinsip kehati-hatian menghasilkan laba yang berkualitas baik (tidak sejalan dengan penelitian Penman dan Zhang (2002).

\section{Pengaruh antara Cadangan Iklan pada Praktik Akuntansi dengan Prinsip Kehati-Hatian terhadap Tingkat Pengembalian Saham}

Penelitian ini menolak hipotesis keenam karena secara statistik reaksi pasar saham tidak menyesuaikan diri terhadap penyampaian informasi baru perusahaan melaluiperubahan kualitas laba yang disebabkan karena penurunan dari cadangan iklan melalui praktik akuntansi dengan prinsip kehati-hatian (sejalan dengan penelitian Penman dan Zhang (2002).

\section{KESIMPULAN}

Berdasarkan hasil penelitian dan pembahasan yang telah dilakukan mengenai pengaruh praktik akuntansi dengan prinsip kehati-hatian terhadap kualitas laba dan tingkat pengembalian saham, menunjukkan bahwa penggunaan akuntansi dengan prinsip kehati-hatian pada perusahaan dapat menciptakan kualitas laba yang baik,akan tetapipasar saham semi kuat seperti di Indonesia tidak memberikan reaksi terhadap perubahan kualitas laba perusahaan yang disebabkan oleh 
Pengaruh Praktik Akuntansi

cadangan persediaan dan cadangan iklan pada praktik akuntansi konservatisme selama periode sampel.

Penelitian ini memiliki beberapa keterbatasan yang kemungkinan mempengaruhi hasil penelitian yaitu sampel penelitian yang digunakan seharusnya meliputi data laporan keuangan perusahaan manufaktur pada tahun 2012 sampai tahun 2014 sebanyak 366 perusahaan, akan tetapi data yang digunakan hanya laporan keuangan perusahaan manufaktur tahun 2012 sampai tahun 2014 sebanyak 252 perusahaan karena data untuk menghitung variabel penelitian tidak tersedia lengkap dalam situs Bloomberg dan situs IDX. Selain itu,pengujian hanya dapat dilakukan selama 3 tahun dikarenakan Indonesia melakukan konvergensi IFRS secara penuh pada tahun 2012 sehingga pengujian tidak dapat dilakukan pada tahun-tahun sebelumnya.

Berdasarkan penjelasan keterbatasan penelitian yang dikemukakan diatas, maka saran yang dapat diberikan yaitu penelitian selanjutnya dapat memperluas sampel penelitian pada sektor lain seperti sektor perbankan, dapat mengembangkan penelitian dengan menguji praktik akuntansi dengan prinsip kehati-hatian menggunakan proksi lain seperti asimetri ketepatan waktu serta mempertimbangkan variabel lain sebagai variabel kontrol yang mungkin berpengaruh terhadap kualitas laba dan tingkat pengembalian saham.

\section{DAFTAR PUSTAKA}

Hellman, Niclas. (2007). “Accounting conservatism under IFRS.”Journal of Accounting and Economics, pp. 1-41.

Latan, Hengky. (2001). Aplikasi Analisis Data Statistik untuk Ilmu Sosial Sains. Bandung: Alfabeta.

Penman, S., dan Zhang.X. (2002).“Accounting Conservatism, the Quality of Earnings, and Stock Returns”.The Accounting Review, Vol. 77, No. 2, pp. 237-264. 